\title{
Accelerating The Achievement Of Participatory Rural Appraisal Based Mdgs Through Empowerment Of Human Resources
}

\author{
Boge Triatmanto ${ }^{1}$, Harianto Respati ${ }^{2}$, Eny Rachyuningsih ${ }^{3}$ \\ ${ }_{1,2}$ (Faculty of Economics and Business, Merdeka University Malang) \\ ${ }^{3}$ (High School of Social Studies and Political Science, Kartika Bangsa Yogyakarta)
}

\begin{abstract}
The study aims to analyze the implementation of poverty reduction through human resource empowerment for optimization of community development using participatory rural appraisal methods. The analysis was done by comparing the implementation of all poverty reduction programs implemented at the field with Participatory Rural Appraisal (PRA) method, resulting in poverty reduction methods based on real problems and potential of particular areas. Descriptive analysis was performed to determine the qualitative response of local government officials, on the perception of Millennium Development Goals (MDG's) success. The results showed that human resource development of local government officials were still not optimally implemented for poverty alleviation activities. The method of poverty alleviation activities was made based on charity, so it has been difficult to justify the sustainability of the program. The achievement of MDG's was already managed quantitatively, but qualitatively it still needed to be improved, especially in the field of public health care in general-that was for MDG's achievement on number four, five, and six. According to the respondents' perception, legal means to preserve the environment have not been implemented.
\end{abstract}

Keywords: Participatory Rural Appraisal, Millennium Development Goals, Empowerment

\section{Introduction}

Efforts to accelerate the achievement of MDG's have become a priority both nationally and regionally; thus, synergy for policy planning at the national level and at the provincial and district/city is necessary. At the local level, MDG's targets should be integrated into the Medium Term Development Planning the form of programs, measurable indicators and targets as well as funding support.

In accelerating the achievement of MDG's, it is necessary to formulate a road map area (Bappenas,2010). Next, the roadmap needs to be translated into MDG action plan in accordance with the conditions and problems in the area. With the Action Plan, it is expected that stakeholders will be more committed and explicit in planning and budgeting programs and activities to accelerate the achievement of MDG's.

Poverty reduction programs have been done in quite big number funded by the state budget (National Program for community empowerment/PNPM Urban, PNPM Agriculture, PNPM Tourism), provincial budget (Movement integrated poverty alleviation), and Revenue Budget Expenditure Regency (APBD) include Village Fun Allocation (ADD) and Pilot Project. But in reality they have not been able to synergistically optimize the achievement of MDG's.

The focus of the present study is on reconstruction on the development of a model for community empowerment programs based on Participatory Rural Appraisal, in order to create models that are better suited to the characteristics of the local community and culture, and is planned to be integrated with regard to the potential of local resources, ranging from institutional structures capable of synergizing institutional built-in poverty alleviation programs in general, that is the Regional Coordinating Team for Poverty Reduction (TKPKD), with elements of the local government (urban/rural), to network with stakeholders and other concerned groups (private business enterprises and state-owned enterprises, non-governmental organizations and universities).

Poverty reduction programs that have been run so far, both programs funded by Revenue Budget Expenditure Regency, such as Village Fun Allocation and pilot project programs, by the provincial budget for movement integrated poverty elevation as well as from by the state budget (PNPM Urban ) and other programs, still relatively weak in terms of program planning to implementation, monitoring and evaluation to accountability reporting; in essence, they have not been managed based on the principles of Participatory Rural Appraisal (PRA), managed in an integration with other development programs, and have not yet synergized optimally for or in alliances with all relevant parties or other concerned groups.

In order for the underlying idea of this study can be answered and elaborated chronologically through clear and accountable research methods then the objectives of the research are as follows: (1) to explore the important factors suitable with the characteristics of local government organizations and community culture as the basis for the development/reformulation model of human resource development programs applied to local 
government officials with the concept of participatory rural appraisal; (2) to make community development programs of the various productive sectors suitable with the characteristics of the local community and local wisdom to achieve potential sustainable community development programs; (3) to determine the compromise between the government's strategy, community self-reliance institutions, private sectors, universities, and groups concerned in poverty alleviation programs to produce independent and sustainable management of community empowerment; (4) to enhance institutional determination according to demographic characteristics of the community in generating participatory human resource development programs.

\section{MDG's Concept Framework}

\section{Literature Review}

Millennium Development Goals (MDG's) refer to national and global commitments in an effort to increase the welfare of the community through the reduction of poverty and hunger, through education, through women's empowerment, as well as through health and environmental sustainability. The eight goals becoming the commitments of MDG's include: (1) eradicate extreme poverty and hunger; (2) achieve universal primary education; (3) promote gender equality and empower women; (4) reduce child mortality; (5) improve maternal health; (6) combat HIV/AIDS, malaria and other diseases; (7) ensure environmental sustainability; and (8) develop a global partnership for development (Bappenas, 2010).

In terms of programs for development purposes, the Millennium Development Goals focus on: (1) programs to eradicate poverty and hunger; (2) programs to achieve basic education for all; (3) programs to achieve gender equality and empower women; (4) programs to reduce child mortality; (5) maternal health programs; (6) programs to control HIV/AIDS, malaria, and other infectious diseases; (7) environmental sustainability assurance program; and (8) support programs to accelerate the achievement of the millennium goals.

\section{The concept of Human Resource Empowerment \& Community Empowerment}

The term personal empowerment related to business consultants and sees it as a powerful analytical tool so they can understand and direct their personal biases, differences of opinions, and experiences of the client in order to succeed in their efforts to change. Regardless of the definition used for this term, empowerment, the end goal is to develop the performance and potential of individuals and organizations.

The fundamental problems in the field of human resource empowerment is due to the fact that the term "empowerment" is associated with the hand over of power/authority, but in practice it is usually seen as a form of involvement of human resources planned by the management with the purpose of increasing the commitment and contribution to the organization. The orientation leads to the individualist and not collectivist, for example, empowerment is based on each worker or group of workers and not on the larger work groups such as labor unions. This includes direct involvement in work practices. Financial participation and representative participation are not part of the agenda, which is by changing the shape difference in to another form related to the involvement of human resources, human resources participation and democracy in the industrial sector. Therefore, there must be a difference between empowerment initiatives as defined above and initiatives directed to effort of empowerment.

Based on this, the empowerment of human resources has crucial role in the performance of an organization and the individual; thus, it needs an effort to improve the human resource capacity and create a culture of empowerment. To improve the ability of human resources is done through training and development or known as human resource development. Creating a culture of empowerment is to create an environment that is conducive to empowerment (Erstad,1997). Furthermore Erstad (1997) describes organizations willing to generate a culture of empowerment must find ways of forming systems and processes that do not restrict human resources. By concentrating on behavior considered to be optimal for human resources and what they have done well, management can adapt, develop, and change the organizational structure to produce better behavior, in which human resources begin to devote theirs attention to learn, grow, and evolve; human resources can take care of themselves; leadership is not only at the top level; high level of trust between management and human resources as well as among human resources; participation of human resources in decision-making; communication is established both vertically and horizontally; and human resources can resolve conflicts with management and obtain an effective and efficient resolution.

In the model developed by Denison (Mobley et al., 2005), empowerment of human resources is one of the indicators in the model of organizational culture. This is in accordance with the argument of Stewart (1998) that empowering others is essentially a cultural change. Empowerment will not work if the entire culture of the organization has not been changed fundamentally (Jarar, 2002; Stewart, 1998).

Empowerment helps eliminate the conditions that cause helplessness while improving self-efficacy, the feelings inside individuals that they are able to complete any job assigned (Newstrom and Davis, 1997). Thus, empowerment is a process to make people become more empowered or more capable to solve their own 
problems by providing trust and authority as to grow responsibility (Kuokanen, et al., 2007; Jarar, 2002)

\section{Participatory Rural Appraisal (PRA)}

Participatory Rural Appraisal (PRA) is a set of approaches and methods that encourage communities (rural) to participate in improving and analyzing their knowledge of life and their own conditions so they can make plans and actions (Chambers,1995). In essence, PRA is a group of approaches or methods allowing people to share, enhance, and analyze their knowledge related to their neighborhood, as well as making plans and concrete actions (Chambers, 1995). Some basic principles that must be met in PRA methods include: mutual learning and sharing of experiences, involvement of all members of the group and information, outsiders as a facilitator, the concept of triangulation, and the optimization of results, practical orientation, and sustainability of the programs (Rochdyanto, 2000).

The method is seen to have had enough operational techniques described through the concept that community involvement is needed in all activities. PRA approach indeed aspires to make people become researchers, planners, and implementers of development and not just the object of development. The focus of the research aspect, however, not on the validity of the data obtained, but the practical value for the development of the program itself.

The application of PRA approaches and techniques can provide greater and more targeted opportunities to involve the community. In addition, through PRA approaches, suitability and appropriateness programs with the needs of the community will be achieved so sustainability of the programs can be guaranteed.

Suyanto (2001) argues that there is still confusion among experts about poverty. Some experts define poverty more on the economic aspects. According to Suyanto (2001), poverty is not simply a lack of income to meet the basic needs of life or a decent standard of living, but more than the essence of poverty is related to the possibility of a poor person or family to develop business and society welfare.

According to Sukartawi (1997), there have been various poverty alleviation programs conducted by the government, private sector, and Non Government Organization (NGO) to reduce the poverty. Various sector programs have been launched by the government, such as Instruction backward village President (IDT) the program was first announced publicly, then the concerned department provides the infrastructure development program included in the program of urban poverty alleviation.

Empowering people is not simply "mobilizing people to take part", but rather to "pursue network partnerships". The focus of community empowerment is on families (family-oriented). The empowerment program contains: (1) building the internal capacity of the family (knowledge, skills, attitudes, and so on), (2) change the beliefs and behaviors that inhibit progress (early marriages, breaches of discipline, and crime), and (3) strengthening of traditional values conducive to development (cooperation, respect), and screening of new values.

The process of community empowerment is an effort to help the community to develop their own abilities as to make them free and able to solve problems and make decisions independently. The empowerment process is done by giving the authority (power), accessibility to resources and accommodating environment.

Community empowerment approach be realized in the participatory development would be very appropriate and can be used to anticipate changes in the environment and their strategic community. The basic concept of participatory development is to undertake development on the basis of meeting the needs of the community it self so that people are able to grow and overcome their own problems in dependently, continuously and sustainability

According to Kumar (2002), empowerment is a dynamic condition which reflects the ability of a social system in realizing the goals or values to which it refers (the dream) (Kumar,2002). In connection with that, the empowerment means efforts (programs, processes) to develop the empowerment of a social system in order to reach the goal independently. As a condition, empowerment is the power generated though the interaction and articulation of culture and human intention to work effectively and efficiently based on accepted norms (ethical, social, political, legal, religious norms) as the reference.

\section{Method}

The design of this study was descriptive qualitative combined with confirmatory exploration. The research variables were derived from the concept of empowerment (Human Resources Empowerment), Participatory Rural Appraisal (PRA), and the eight dimensions of the concept of MDG's which can be the basis for determining empowerment management scheme that is competitive and sustainable.

The method of analysis used was the mixed method combining descriptive qualitative analysis and quantitative analysis. Descriptive qualitative analysis was used to explain the relationship between variables based on the opinions or ideas of the respondents (regional work units and community self reliance agency) to explore the depth of the programs on the run and examine the expectations of society towards poverty reduction programs. The other analysis used factor analysis to produce a crystallization of dominant dimensions able to 
form a variable.

The population of the study is on regional work units (SKPD) which consists of a number of departments and agencies as many as 41 SKPD which implement poverty reduction programs in accelerating the achievement of MDG's. The sampling technique was purposive sampling and the documentation as needed by the analysis.

\section{Result}

The percentage of poor people (i.e. poor and nearly poor) in Batu town from 2008 to 2011 continues to decline in which in 2008 it was 11.39 percent, 10.55 in 2009, and 9.83 in 2010. Mean while, for the year 2011 it was 8.52 percent with an average rate of decline of 5.97 percent per year (Bappeda of Batu town, 2012). This figure has been below the national standard of eleven percent (11 percent). At this time the figure for East Java is predicted to remain above 11 percent.

The decline in poverty caused by the impact of the policy in addition to the priority development programs, as well the implications of special treatment of the local government's commitment to improve the welfare of the community through community empowerment in both rural and urban areas.

Priority policies implemented to address the problem of poverty including Rural Community Empowerment Improvement Program, Development of Economic Institutions in Rural Community, and Improvement of Community Participation in Village Development. These programs aim to foster community

\section{Figure 1 The percentage of poor people in Batu town (2005-2011)}

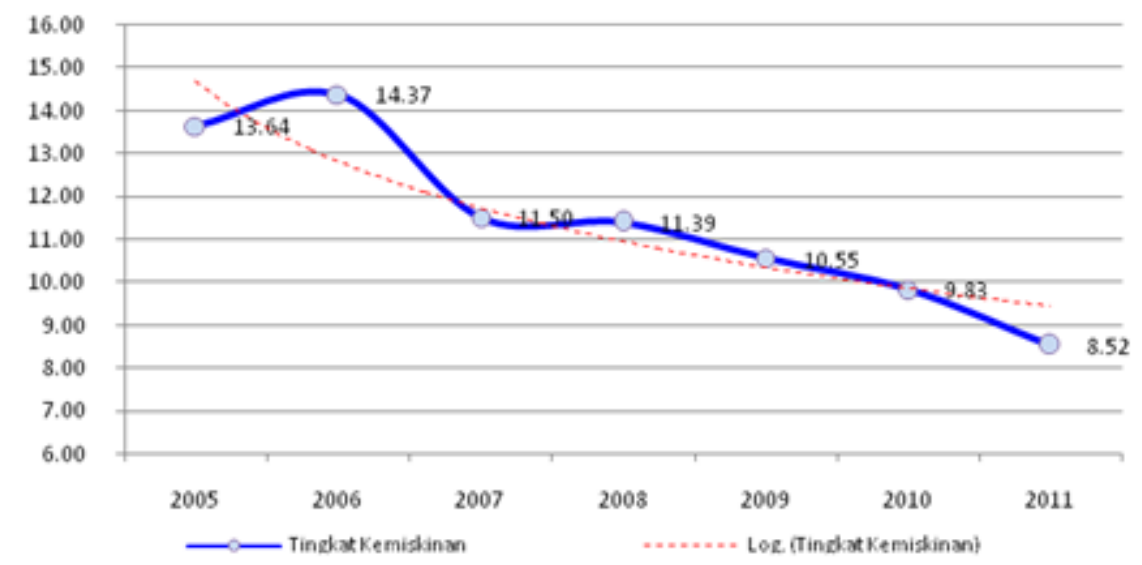

Source: Bureau of Central Statistics (BPS) of East Java, 2010 and the Results of Analysis

self-reliance through load reduction and improving quality of life of small communities, meeting the basic needs of rural community, business development, expansion of employment and income generation, community empowerment based on social capital and local culture, and social issues management.

Based on data from Bureau of Central Statistics (BPS), the number poor in Batu town were 5,817 households out of the total 55,136 house holds. That number becomes the basis for distribution of rice for the poor at the same year. Based on that data, the poverty rate in 2009 reached $10.55 \%$. Figure 1 shows that the poverty rate in 2008 was quite high at $12.59 \%$ and above the national frontier of $11.00 \%$. This was because of rising prices of basic commodities, especially fuel, triggered by the out break of the global financial crisis.

The numbers of poor families that include nearly-poor, poor, and poorest predicted to reach 5,635 household, or $9.83 \%$; this means a decrease compared to the previous year. The cumulative number of poor families sex experienced a sustainable decline in average rate of- $6.35 \%$ per year since 2005 . When calculated based on the number of poor families using BPS poverty line standard, the poverty rate in 2010 was $4.81 \%$ and the lowest number in between all local governments in the province of East Java. At the same time, the number of poverty of areas bordering the Batu town was $5.58 \%$ for Malang town, $13.57 \%$ for Malang regency, and $13.24 \%$ for Mojokerto town. This is a record of achievement that needs to be maintained and even improved in the up coming years.

\section{Discussion}

The overall mean indicators of each variable in this study can be presented as follows: 
Accelerating The Achievement Of Participatory Rural Appraisal Based Mdgs Through ....

Table 1 Variables and Mean Indicator

\begin{tabular}{|c|c|c|c|}
\hline Variable & Indicators & Number of items & Mean Indicators \\
\hline \multirow{5}{*}{$\begin{array}{l}\text { Empowerment of human } \\
\text { resources }\end{array}$} & Level of participation & 2 items & 3.635 \\
\hline & Level of initiatives & 2 items & 3.570 \\
\hline & Level of commitment & 2 items & 4.125 \\
\hline & Level of responsibility & 2 items & 4.060 \\
\hline & Mean Variable & & 3.846 \\
\hline \multirow{6}{*}{$\begin{array}{l}\text { Participatory Rural } \\
\text { Appraisal }\end{array}$} & Attitude \& behavior & 4 items & 3.780 \\
\hline & Involvement & 4 items & 3.533 \\
\hline & Facility & 3 items & 3.623 \\
\hline & Optimization of results & 3 items & 3.273 \\
\hline & Program sustainability & 3 items & 3.633 \\
\hline & Mean Variable & & 3.569 \\
\hline \multirow[t]{8}{*}{ Achievement of MDGs } & Eradication of povertv and hunger & 3 items & 3.663 \\
\hline & Basic education for all & 3 items & 3.637 \\
\hline & Gender equality & 3 items & 3.547 \\
\hline & Reducing child mortality & 4 items & 3.760 \\
\hline & Improving maternal health & 3 items & 3.577 \\
\hline & Controlling infectious diseases & 3 items & 3.443 \\
\hline & $\begin{array}{l}\text { Environmental sustainability } \\
\text { assurance }\end{array}$ & 3 items & 3.693 \\
\hline & Mean Variable & & 3.617 \\
\hline
\end{tabular}

In variables of empowerment of human resources, the indicator having the highest value is the level of commitment with an average value of 4.125; the second is the level of responsibility with an average value of 4.06; the third is the level of participation with an average value of 3.65 and the latter is the level of initiative with an average value of 3.57. From this analysis it can be concluded that the human resource empowerment in poverty reduction programs in SKPD has already run, indicated by the mean value of the variable of 3.84 . However, empowerment done is still not optimal indicated by the mean value of the level of human resource empowerment that is employee participation in poverty reduction programs which is still quite low. It is also shown by the relatively low mean value of the level of initiative. Optimization of employee participation in poverty reduction programs still need to be more elevated. This can be done through the participation of employees in the poverty alleviation programs funded by APBD of Batu town, for example in the Village Fund Allocation (ADD) and other funding for poverty reduction programs.

Variable Participatory Rural Appraisal (PRA) has an average value of 3.568. This value illustrates that poverty reduction activities undertaken by SKPD are generally not based on PRA. This can be demonstrated from the mean value of each indicator in PRA variable. The first indicator of attitudes and behaviors has a mean value of 3.78, the highest among other indicators. In general this indicator examines the attitudes and behavior of employees of SKPD in poverty reduction activities in which they should serve as a facilitator from outside the villages facilitated. The mean value indicates that the average employee attitudes and behaviors in the implementation of poverty reduction programs are in accordance with the provisions of PRA model, but not optimal this may due to the fact that employees just want to do their routine work and not as a facilitator in a project.

The first variable on community empowerment shows that employee involvement in poverty reduction activities is still not optimal. It appears from the employees' perception of empowerment performed by the human resource staff of the government. Therefore, we need to optimize the empowerment of governmental human resource.

The second variable of Participatory Rural Appraisal (PRA) shows that this method has not been fully implemented in nearly all poverty alleviation activities undertaken by SKPD and the poverty alleviation activities undertaken by SKPD are "charity-based", and yet they do not genuinely empower people. Thus, we need good examples (best practices) of the application of PRA method to empower people in poverty reduction.

The third variable is MDGs achievement. Based on the perception of the respondents, they are still not optimally achieved by the local government, in particular the achievement in the prevention of infectious diseases. Based on empirical data, the first MDG goal (reducing poverty and hunger) has been reached, and up to 2013 poverty reduction rate has reached $4.5 \%$. However, until now the number of people suffering HIV/AIDS, based on the data from the Commission on HIV/AIDS, has increased; thus, there is a paradox between empirical achievements of the MDGs with field conditions.

Based on these conditions, the plan for the next stage of the study is to conduct research in grassroots level or targeted community to implement poverty reduction activities. In this case, self-supporting organizations or institutions receive, manage, and oversee the implementation of poverty alleviation activities, both derived from the city or local budget, provincial budget and the state budget. This is done to obtain information and empirical results on poverty reduction programs. 
The study was conducted by comparing perception on the achievement of MDGs by employees on SKPD with the community that has been empowered; for all activities funded by the city budget, provincial budget, and the state budget. This is done to get an idea about the actual condition of human resource implementing poverty alleviation activities in Batu town.

\section{Conclusion And Limitation}

The involvement of SKPD employees in poverty reduction activities is still not optimal. It appears from the employees' perception on empowerment performed on human resource employees working for the local government of Batu town. Thus, we need to optimize human resource development of employees working for the local government of Batu town

Implementation of poverty reduction by using Participatory Rural Appraisal (PRA) has not been fully implemented in nearly all poverty alleviation activities undertaken by SKPD and the poverty alleviation activities undertaken by SKPD are "charity-based", and yet they do not genuinely empower people. Thus, we need good examples (best practices) of the application of PRA method to empower people in poverty reduction.

In the implementation of community empowerment, it is expected to empower more human resources working for SKPD; in this regard the programs would be more effective for poverty reduction activities originating from the budget of SKPD.

However, for the implementation of poverty reduction programs using PRA method to be more effective, outsiders should be involved. This is in accordance with PRA method development (Chambers, 1995). Updates of data must be done on an ongoing basis to obtain more accurate data on the poor as to avoid conflicts in society and empowerment of the poor is done to the right target by the right people.

\section{Further Research}

Based on the perception of the respondents, the achievement of MDGs are still not optimally achieved by the local government, in particular the achievement in the prevention of infectious diseases. Based on empirical data, the first MDG goal (reducing poverty and hunger) has been reached, and up to 2013 poverty reduction rate has reached $4.5 \%$. However, until now the number of people suffering HIV/AIDS, based on the data from the Commission on HIV/AIDS, has increased.

There is a paradox between empirical achievement of MDGs with the achievements of poverty reduction and hunger. That is, poverty and hunger has decreased, but the number of people with HIV / AIDS has increased. The rate of maternal health is also stagnant; many respondents were undecided or chose number 3 to perceive the fifth MDG achievement.

\section{Acknowledgement}

Our gratitude is addressed to the Ministry of Education and Culture, Directorate of Research and Community Service on financing this study through Coordinator of Private Universities (Kopertis) Region VII Surabaya city, and to Regional Development Planning Board (Bappeda) Batu East Java Province, Indonesia, which has collaborated in the implementation of the study.

\section{Note on the First Contributor}

Boge Triatmanto is a lecturer at the Faculty of Economics and Business Management Merdeka University Malang, Indonesia. His research interest is in human resource management, human capital, and organizational development.

\section{References}

[1]. Bappenas, Kementerian Perencanaan Pembangunan Nasional/Badan Perencanaan Pembangunan Nasional (Bappenas), Laporan Pencapaian Tujuan Pembangunan Milenium Di Indonesia 2010, Jakarta, 2010

[2]. Bappeda Kota Batu, , Badan Perencanaan Pembangunan Daerah, Kota Batu, Laporan Monitoring dan Evaluasi MDG's Kota Batu, Provinsi Jawa Timur. 2012

[3]. Chambers, R dalam Putnam R D, Bowling Alone: America's declining social capital, Journal of Democracy, 6 (1),1995, pp 65-78,

[4]. Erstad, Margaret, Empowerment and Organizational Change, International Journal of Contemporary Hospitality Management, 9(7), 1997, 325-333

[5]. Jarar, Yasar F.and Mohamed Zairi, Employee empowerment - a UK survey of trends and best practice, Management Auditing Journal, 17 (5), 2002, 266 - 271.

[6]. Keputusan Wa!i Kota Batu Nomor: 180/105/Kep/422.013/2008, tentang Pedoman Umum Alokasi Dana Desa untuk Program Pemberdayaan Masyarakat. Tahun Anggaran 2008.

[7]. Kumar, Kamalesh, Market Orientation - Organizational Competencies and Performance: An Empirical Investigation of a PathAnalytical Model, Journal of American Academy of Business, 2002, 371

[8]. Kuokkanen, Liisa, Tarja Suominen, Sirku Rankinen, Marja Leena, Kukkurainen, Nina Savikko, and Diane Doran, Organizational Change and Work-related Empowerment, Journal of Nursing Management, 15, 2007, 500-507.

[9]. Mobley, William H., Lena Wang and Kate Fang, Organizational Culture: Measuring and Developing it in Your Organization, Knowledge @ CEIBS-Summer, 2005

[10]. Newstrom, John W., and Keith Davis, Organization Behavior, (Singapura: The McGraw-Hill Inc, 1997). 
[11]. OECD, Societal Cohesion and the Global Economy, (http: //www.oecd.orQ/dataoecd/38/19/17724730.pdf :1997)

[12]. Hasil Penelitian Pusat P3R-YAE, Penanggulangan Kemiskinan di Sulawesi Tengah, Bogor, 2010

[13]. Spellerberg A, Framework for the Measurement of Social Capital in New Zealand, Research and Analytical Report, 14, Statistics New Zealand -Wellington, 2001

[14]. Soekartawi, Strategi Mengentas Kemiskinan di Indonesia Melalui Impres Desa Tertinggal, Jurnal Studi Indonesia, 7 (2), 1997

[15]. Stewart, Jenny, and Michael O'Donnell, Implementing Change in a Public Agency, Leadership, Learning and Organizational Resilience, International Journal of Public Sector Management, 20 (3), 2007, 239-251.

[16]. Sumintardja and Elmira N., Faktor Determinan Pembentuk Kepribadian Manusia Indonesia yang Mencerminkan Perilaku Sehat Mental dalam Tatanan Budaya Kolektif, Jurnal Ilmu-Ilmu Sosial dan Humaniora Padjadjaran, Lembaga Penelitian Universitas Padjadjaran Bandung, 3 (1), 2002

[17]. Suyanto, Bagong and Karnaji, Rencana Induk Pengentasan Kemiskinan di Surabaya, (Surabaya: Lutfansah Mediatama Press, 2001)

[18]. Swasono and Sri,Edi, Pembangunan Menggusur Orang Miskin Bukan Menggusur Kemiskinan, Diskusi Bulanan Pusat Studi Ekonomi Pancasila UGM bulan September, Yogyakarta, 2004, 1-10

[19]. World Bank, World Development Report 1999/2000 (Entering the 21st Century, New York: Oxford University Press, 2000). 